\title{
Exploration of Problems and Countermeasures in the Higher Education International Class Teaching
}

\author{
Wei Liu ${ }^{a}$ and Ziyang $\mathrm{Cao}^{\mathrm{b}}$ \\ Suzhou University of Science and Technology, Suzhou, China \\ a liuwei_nuaa@163.com, ${ }^{\text {b }}$ dukeczy@nuaa.edu.cn
}

\begin{abstract}
Keywords: Higher education; Chinese-Foreign cooperative education; International class; Foreign teaching methods
\end{abstract}

\begin{abstract}
As an important form of internationalization of higher education, international class has trained a large number of excellent international talents in China by the way of Chinese-foreign cooperation in running schools in recent years. However, the differences between foreign teaching methods and domestic traditional teaching methods have brought some new problems to actual teaching. Taking the mechanical engineering international class in Suzhou University of science and technology as an example, this paper describes overseas teaching methods in the international class, analyzes the existed problems and puts forward the corresponding countermeasures in order to obtain good teaching effect.
\end{abstract}

\section{Introduction}

In terms of educational philosophy, academic level and teaching conditions, there is still a considerable gap between the domestic first-class foreign universities and domestic universities. An important method of shorting the gap is participating in international communication and cooperation actively [1,2]. International cooperation is conducive to introduce foreign advanced teaching content, ideas and modes, study advanced management methods, promote the transformation of domestic university in terms of teaching philosophy and reform [3,4] to train high-quality, internationally competitive human resources for our country [5]. Therefore, more and more colleges and universities began to implement the international class [6,7], which is a cost-effective Chinese-foreign cooperative education mode with good teaching condition. Mechanical design manufacturing and automation of Mechanical Engineering College in Suzhou University of science and technology has enrolled the international class since 2012. International class teaching is divided into two stages: After a period of 3-year English, basic courses and professional courses study in China, students who reached the requirements of the school will go to the University of South Wales English and study professional course in the fourth year. In order to let the students gradually adapt foreign teaching methods, every foreign teacher is arranged to teach a course in every semester.

\section{Foreign Teaching Methods Implemented by International Classes}

Foreign teaching methods are very different from the domestic. Domestic teachers' teaching is generally more directly, clarifying directly what they teach in class, which can make students get knowledge directly but not conducive to train students' independent thinking and learning ability. When foreign teachers give students a class, they usually pay more attention to arousing the students' enthusiasm and initiative [8,9], and encouraging students to ask and answer questions; Flexible and diverse teaching methods and forms are used to enhance the students' interest in study. Besides that, they pay more attention to interacting with students and giving students questions to think, and emphasize students' autonomous learning, cooperative learning and inquiry learning in class. They often arrange students some design courses after class. Students are required to pay more time to searching information, thinking independently and communicating with each other. They express and show their work with multimedia to exercise expression ability. All these stimulate students' 
innovative thinking, train students' autonomous learning, independent analysis and team cooperation ability, improve students' ability of speaking academic report and writing academic papers, and strengthen students' understanding of knowledge. Students feel they have learn more and they are better at thinking, analyzing, finding and solving problems.

\section{Exposed Problems in the Implementation of Teaching}

Students' uneven English foundation. In recent years, the large-scale enrollment of colleges and universities has reduced the quality of College students. Especially, non-English majors' listening and speaking abilities are generally not very good. Some foreign teachers lack for understanding Chinese students' foreign language proficiency and characters before class. Extroverted students with a good English foundation can get good exercise. However, most introverted students with poor English foundation are always due to lack of confidence and choose silence, which makes them gradually become classroom audiences rather than participants. This is likely to lead to silent students gradually lose interest in foreign teachers' teaching.

Students' Inadaptation of Foreign Teaching Methods. Through the first international class of students on the international curriculum survey, $12.1 \%$ of the students said that the pressure is very large, $72.7 \%$ said there is pressure and the $15.2 \%$ is no pressure. Differences in teaching methods make some students can't adapt to foreign teaching methods, which reflects in not good learning effect and less communication with foreign teachers. There are two main reasons. One is English teaching increases study difficulties. More course preparation is necessary for a good grasp of the class content and good study effect. The other one is due to cultural differences. Because the students are lacking for the tradition of encouraging expressing themselves and accustomed to passive cramming teaching, they take the initiative of self-reflection in class and respond positively to the teacher's question rarely, which leads to poor communication effect.

Mismatching between Teaching, Management and Foreign Teaching Methods. The teaching and management of international class are separated. Teaching belongs to the College of Mechanical Engineering, but management belongs to the College of International Education. The separation causes the students lack strict management. For a long time, many students become lazy and slack at study and can't have a good self-management and constraints, which brings the class poor study atmosphere. Students are hard to study foreign teachers' courses with efficiency. In addition, appraisal system does not accord with the abroad. For example, the foreign teachers prefer to taking homework and curriculum design as evaluation forms. But we insisted on paper test, which can't adapt to foreign teaching and makes many foreign teachers change much content to cater to paper test.

\section{Solution of the Problems}

Multiple Ways to Improve Students' English Proficiency. In English study, the students should be divided into different classes according to their English proficiency and the students with poor English should be cared more to improve English. More bilingual courses should be set up, so that students have more opportunities to have English study. The English communication activities should be held regularly, and students can exercise the ability of listening and speaking, which can also stimulate students' interest in English in a relaxed atmosphere. Besides that, international class teaching can make full use of network and multimedia. Multimedia contains a large amount of information and is easier to show more English content so as to make students study English more conveniently. In addition, in the course teaching, foreign teachers' video can also be introduced to stimulate students' interest in study and improve their English proficiency.

Providing Teaching Assistants. Foreign teachers' courses usually last only two weeks, so that the time is not enough for students' course preparation and review, which gives students heavy burden and brings bad influence on the teaching effect. To solve these problems, it is very necessary for every international course to provide a teaching assistant who is familiar with the course. The main duties of 
TAs are: (1) Assisting foreign teachers to teach, helping students study the content of courses and communicate with teachers. (2) Carrying out pre-class coaching before class, introducing the relevant background include the basic framework, main content, background knowledge, etc.. (3) The teaching assistants attend the lecture and solve problems in time to help teachers and students to communicate well with each other. (4) Helping students review and summarize teaching contents, answering their questions.

Strengthening Daily Management. The foreign teachers' courses last two weeks and the teaching time is 3.5 hours every day, which makes students tired and hard to study full of energy. So non-essential items are necessary to avoid for less burden and more attention to completing courses in the teaching period. Counselors should also strengthen daily management of international classes. Because students have many international courses, daily activities can be carried out around English to increase opportunities for English improvement, especially junior students. Multi way of examination, supervision and talking can be used to stimulate students' interest in study and create a good study atmosphere. In addition, enough autonomy should be given to foreign teachers. Domestic standard should not be imposed on foreign teachers but their teaching methods are fully carried out.

\section{Summary}

Chinese-foreign cooperation in running schools and the introduction of foreign advanced teaching mode and idea are beneficial to import western resources of colleges and universities and train high-quality students with international, global vision. International class is one of the most important forms of running schools. There is no unified teaching mode in various colleges and universities. Only in the way that problems are found in practice and solved step by step can an effective international class teaching mode be explored for domestic universities, which is beneficial to cultivate high-quality international talent.

\section{Acknowledgements}

This research is supported by the teaching reform and research project of Suzhou University of Science and Technology in 2015 (2015JGM-20).

\section{References}

[1] S.H. Hou and Y.M. Fan: Teaching practice and exploration of university international class higher mathematics [J]. China electric power education, (2012) No.32, p.45-46. (In Chinese)

[2] Y.X. Huang and C.G. Chen: Three deviations of China's universities internationalization development and their correction [J]. Journal of Higher Education, Vol. 35 (2014) No.12, p.54-58. (In Chinese)

[3] F. Liu and M. Zhao: Internationalization of higher education and university international cooperation and exchange [J]. Continue Education Research, (2007) No.1, p.113-115. (In Chinese)

[4] M. Ye: Current condition and inspiration of college's international cooperative school-running [J]. Journal of Xianning college, Vol. 27 (2007) No.4, p.30-31. (In Chinese)

[5] M. Zhou and S.C Ding: University internationalization strategy: framework and way research [J]. China higher education research, (2011) No.9, p.16-19. (In Chinese)

[6] X.Y. Zhang: Present situation and developmental strategies of university sino-foreign cooperative education [J]. Science-technology and management, Vol.7 (2005) No.4, p.29-31. (In Chinese)

[7] H. Huang: Rearch on local university higher education internationalization problems [J]. Education teaching forum, (2015) No.33, p.88-90. (In Chinese) 
[8] W.Q. Yao: Present situation and thinkings of university international cooperative education in our country [J]. Journal Liaoning Administration College, Vol. 11 (2009) No.9, p.117-118. (In Chinese)

[9] J.T. Ma and B. Wang: Training model of postgraduate's international class in universities [J]. Survey of Education, Vol. 5 (2016) No.21, p.105-107. (In Chinese) 